\title{
椅坐位からの立ち上がり動作の分析
}

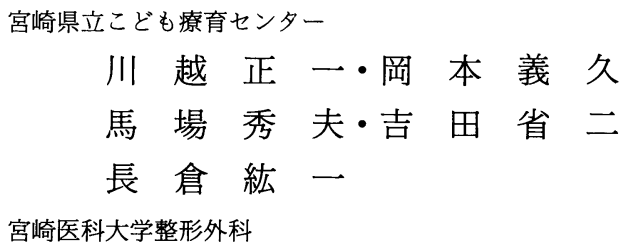

田島 直 也・山口一 郎

\section{Studies of the Movements in Standing Up from a Chair}

by

\author{
Shouichi Kawagoe, Yoshihisa Okamoto, Hideo Baba \\ Shouji Yoshida and Kouichi Nagakura \\ Miyazaki Prefectural Crippled Children's Hospital \\ Naoya Tajima and Ichiro Yamaguchi \\ Department of Orthopaedic Surgery, \\ Medical College of Miyazaki, Miyazaki
}

\begin{abstract}
In order to evaluate the influence of the height of a chair and the location of the feet during standing up, ten adult persons were examined on the floor-reaction-force and the angular velocity with the system of LOCUS III-D.

When a chair was low and the location of the feet was set anteriorly, the standing up was done with some difficulty, and the floor-reaction-force was characteristic. Namely fore component and external component appeared. Hip joints and trunk were extended before knee joints to gain the fore decceleration force and upper acceleration force. Besides the height, it is very important for regarding the structure of a chair whether we can pull back our feet.
\end{abstract}

椅子やベッドからの立ち上がり動作は，立位への移 行段階として, 大変重要である。体幹や四肢に機能障 害を有する場合, この動作時に痛みや不安定感などを 生じ,歩行以上に困難をきたすことがしばしばである. 今回, 立ち上がり動作について, 椅子の高さ, 足の位 置との関連性を含めて検討した.

\section{対象と方法}

健康成人男性 10 人を対象とした. 平均年令 $30.2 \pm$ 7.2 才, 平均身長 $172.9 \pm 5.1 \mathrm{~cm}$, 平均下腿長 $38.8 \pm$ $2.4 \mathrm{~cm}$ である.

装置はアニマ社製 LOCUS-3 D（光学式三次元位置 計測システム) である。椅子は, 脚がフォース プレ
ートをまたぐ形とした. そして, 左前方と後方の二方 向よりセンサカメラで LED (赤外発光ダイオード) マ 一カーを捉えるため, マーカーを椅子の脚が隠さない 様に坐面を斜めにし，また，起立時にその影響が出な いように, 大腿後面があたる場所に切れ込みを入れて いる（図 1 ）。被験者は左側の耳珠点, 肩峰, 腸骨稜, 大転子, 膝関節点, 足関節点, 第五中足骨頭に LED マ 一カーを付けた. 椅子の高さは $30 \mathrm{~cm}, 40 \mathrm{~cm}, 50 \mathrm{~cm}$ とし, 足の位置を, (1)下腿軸が床面に垂直の場合, (2)

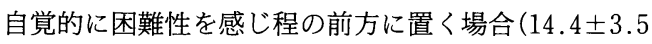
$\mathrm{cm}$ 前方), (3)任意に後方に置く場合としそれぞれの組 み合わせで, 5 回のトライアルを行った. 歩隔, つま 先開き角は任意とした. 各トライアルの取り込み時間 
を $5 \mathrm{~s}$, 取り込み周期を $20 \mathrm{~ms}$ とし, 起立動作後, 1 ポ ーズの後, 左足より歩行することとして検討した.

\section{結果}

比較的起立しやすい条件(椅子の高さ： $50 \mathrm{~cm}$, 足の 位置：後方）と，起立しにくい条件 $(30 \mathrm{~cm}$, 前方) の トライアルを例にとる（図 2 ).

\section{1）床反力}

垂直分力 $(Z)$ は，重心が前方に移動しはじめた時

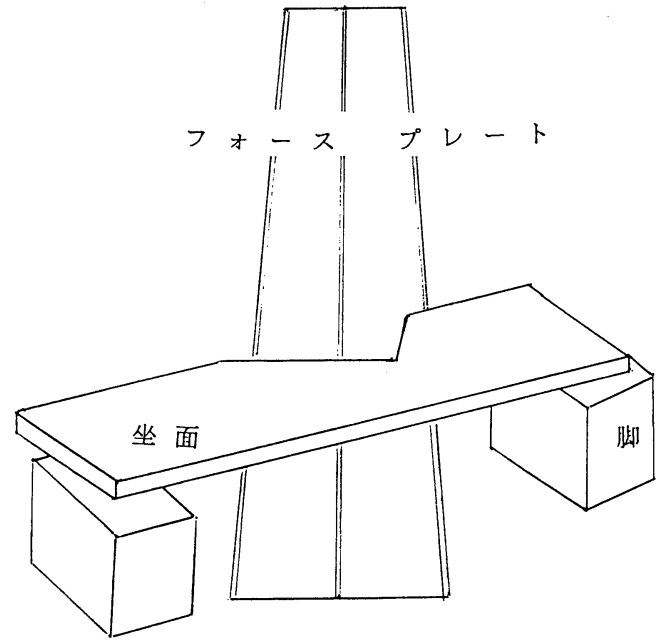

図 1 椅子の脚がフォース プレートをまたバ形とし た．坐面を斜めにして，大腿後側部があたる場 所に切れ込みを入れている。

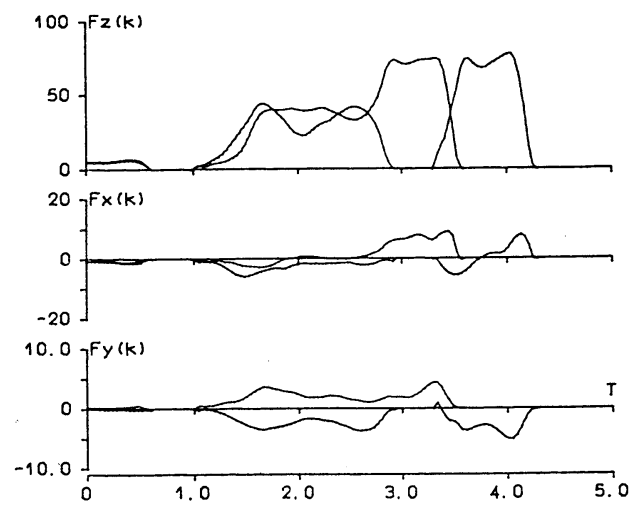

(a)
点で出現し, 椅子から離れる即ち離坐により急激に増 大し，起立完成前にピーク值を呈する，その後歩行準 備段階として，最初の遊脚側である左下肢の垂直分力 が, 右より明らかに大きくなる. 前後分力 $(X)$ は $Z$ 分 力が最大の時, 後ろ向き (一) になっている. (一)一 相性のこともあるが, $Z$ の立ち上がりに一致して,$(+)$ 分力が一時的に生じ，二相性となることがある。これ は，椅子が低い程，また足の位置が，前方にある程生 じやすい. 側方分力 (Y) は内側向き反力の一相性の場 合と, 外側向きから内側向き反力の二相性の場合があ る. 椅子の高さが低い程, また, 足が前方にある時程, まず外側向きの分力が現れている.

それぞれの分力の左右合計のピーク值を体重で正規 化して，椅子の高さと足の位置の相関性を検討した。

(1) 垂直分力 $(Z)$

椅子の高さとの関係：下腿が垂直，あるいは足が後 方の時, 椅子が高くなると, 垂直分力は有意に小さく なる.

足の位置との関係：足が前方のにある場合は, 垂直 の場合に比べて大きい傾向はあるが，有意差が見られ るのは，椅子の高さが $50 \mathrm{~cm}$ の時のみである（図 3 ).

(2) 前後分力 $(X)$

前方分力（+）：椅子が低い程，また，足の位置が 前方にある時程, (十) 分力は大きくなり, 有意差を認 めることが多い.

前後分力〈(+) と（一）を加えたもの〉：いずれの
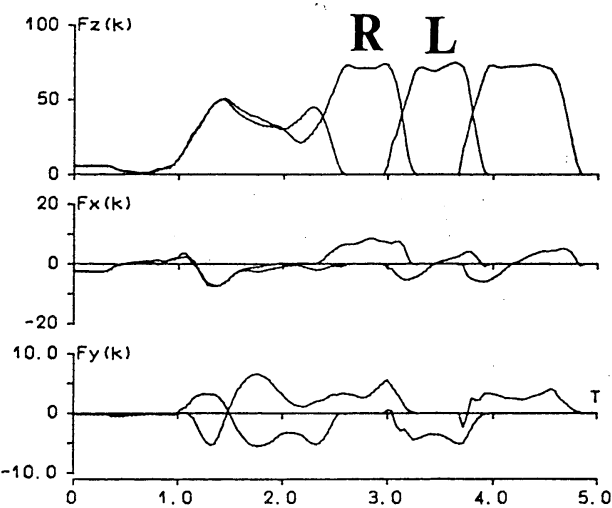

(b)

図 2 床反力

(a)：椅子の高さは， $50 \mathrm{~cm}$. 足の位置は後方.

(b)：椅子の高さは, $30 \mathrm{~cm}$. 足の位置は前方.（前方分力, 外側分力の出現をみる) 


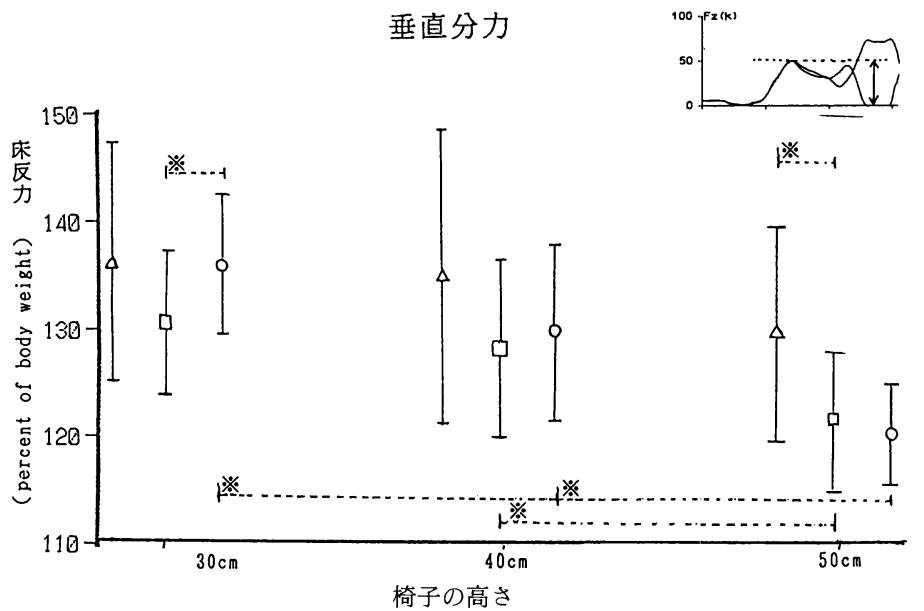

図 3 垂直分力：椅子の高さ，足の位置との相関性 $\quad \%: p<0.01$

足の位置： $\triangle$ (前方), $\square$ (垂直), $\bigcirc$ (後方)

高さにおいても, 足の位置が前方の場合は, 有意に大 きくなる(図 4 ).

(3) 側方分力 (Y)

内側向きの反力の大きさと, 椅子の高さ及び足の位 置との相関は明らかでない.一方, 外側向きの反力は, 椅子の高さが低い程, また, 足の位置が前方の時程, 有意に大きくなる（図 5 ).

2) 角速度

足の位置が後方の場合, 膝の伸展が生じ, その後, 股関節や体幹が，伸展しはじめる，足の位置が前方の 場合は, 膝の伸展に先立って, 股関節や体幹の伸展が 生じる(図6)。

\section{考}

察

1985 年岩倉らは, 腰掛け姿勢およびしゃがみ姿勢か らの立ち上がり動作時の筋活動と姿勢調節について検 討を行った ${ }^{2)}$.また, 1989 年橋本らは, 起立動作の分析 を椅子の高さを変えて行っており, 下腿長の約 1.2 倍 の椅子の高さの時, 後方への分力が小さく, 内方への 分力が大きく出現し, 歩行への移行がしやすいと, 述 べている1).

今回は, 椅子の高さに加えて, 膝に対する足関節点 の前後位置についても，検討を行った(図 7 ). 足の位 置が前方に位置するときは, 離坐する前に骨盤や体幹 をより前方に倒す。しかし，これのみでは，足底の床 反力作用点より重心がかなり後方に位置するため, 前 方への床反力を作用させて, 足関節を軸として, 上体
をより前方に移動させる．この際，側方分力は外側方 向である，重心が床反力作用点に近付いて来ると，骨 盤や体幹を伸展させ，後方への床反力を作用させる. これにより重心移動速度は低下し，同時に垂直方向に 大きい床反力を作用させ，㯟を伸ばし立ち上がる，床 反力の側方分力は, ここでバランス保持の要素が強く なり，内側方向となる.

椅子の高さが低いと, 離坐前の骨盤や体幹の前傾に よる重心の前方移動が効果的でないため, 足の位置が 前方の場合と似たメカニズムでの起立となる.

足の位置が後方の場合, 離坐する前の体幹の前傾に よって, 重心は床反力作用点にかなり近付くので, 重 心はそれ以上急速に前方に移す必要なく, 膝を伸ばし ながら, 後方一内側への床反力にて, 離坐前に生じて いる重心の前方速度を減ずる. 体幹は, バランス取り ながら伸ばしていく.

以上より，立ち上がり動作を困難と感じるのは，離 坐時に重心と床反力作用点との前後方向の距離が大き く，そのため重心の急激な前方移動とその直後の停止 または，後方移動が必要な時と考えられる，また，床 反力の前方分力と外側分力は, 困難性を訴えやすい条 件にて出現していることが解る（図 8 ）。

よって，立ち上がり動作の容易な椅子とは，ある程 度の高さを持ち, 足を引くことの出来る構造になって いる物であり，体幹や四肢に機能障害を有する人々に ついては，特に注意が必要である. 


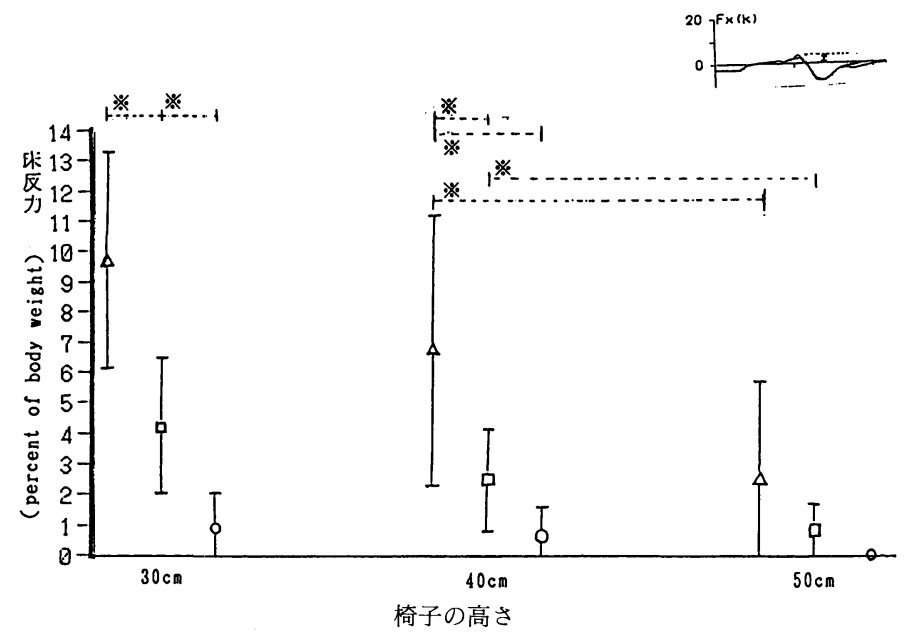

(a) 前方分力
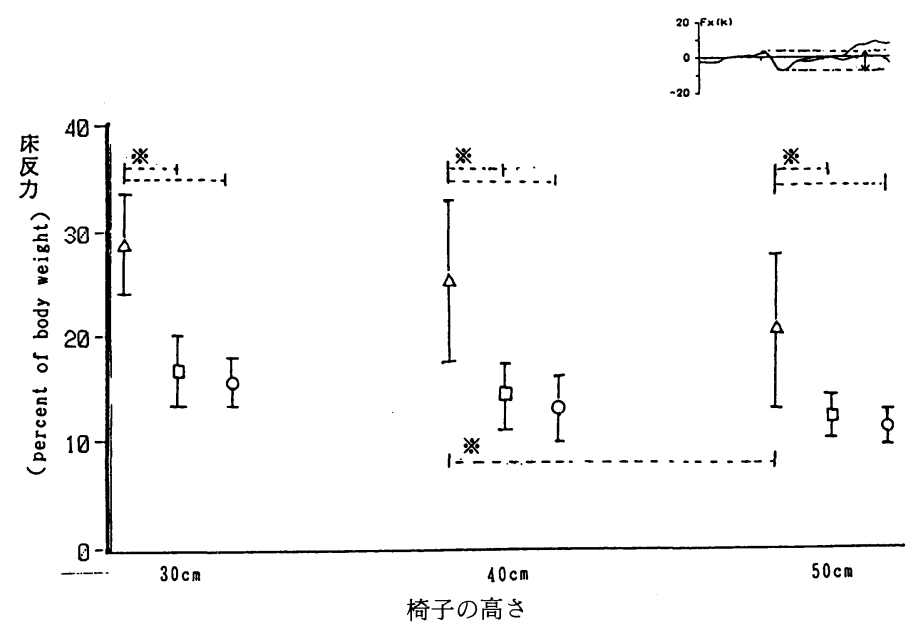

(b) 前後分力

図 4 前後分力 : 椅子の高さ, 足の位置との相関性 $※: p<0.01$

足の位置 : $\triangle$ (前方), $\square$ (垂直), $\bigcirc$ (後方) 

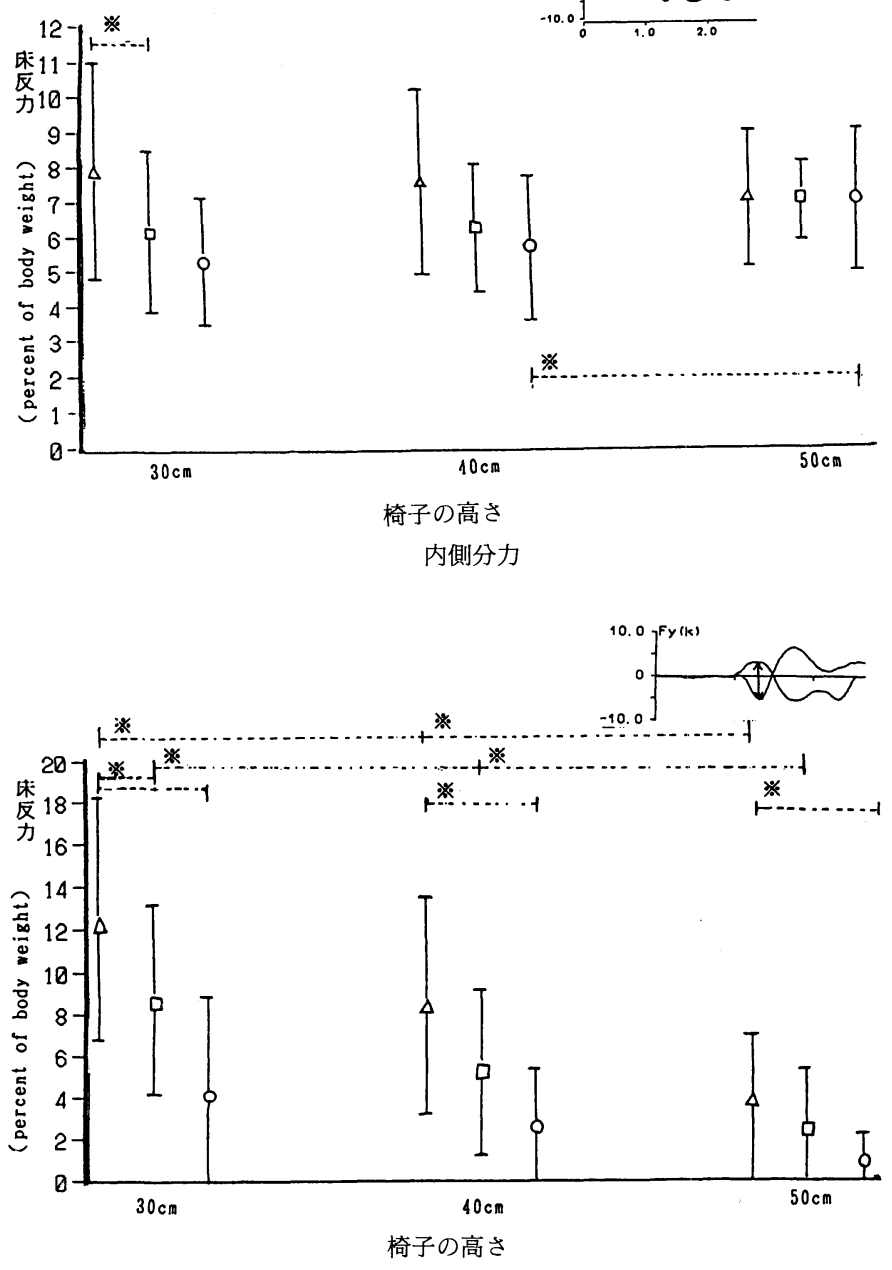

(b) 外側分力

目 5 側方分力：椅子の高さ，足の位置との相関性 $※: p<0.01$

足の位置 : $\triangle$ (前方),$\square$ (垂直), $\bigcirc$ (後方) 


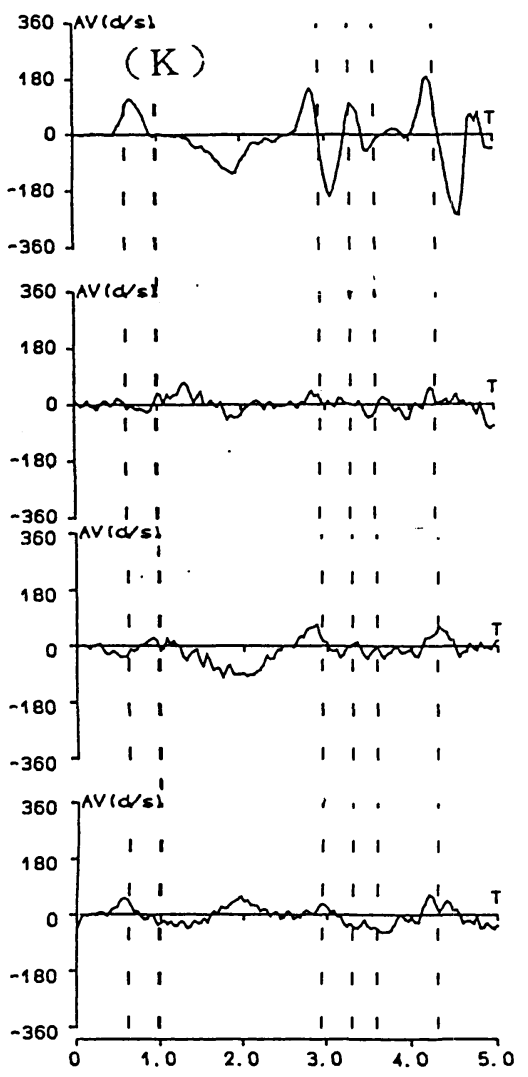

(a)

\section{膝関節}

股関節

体幹

頝部

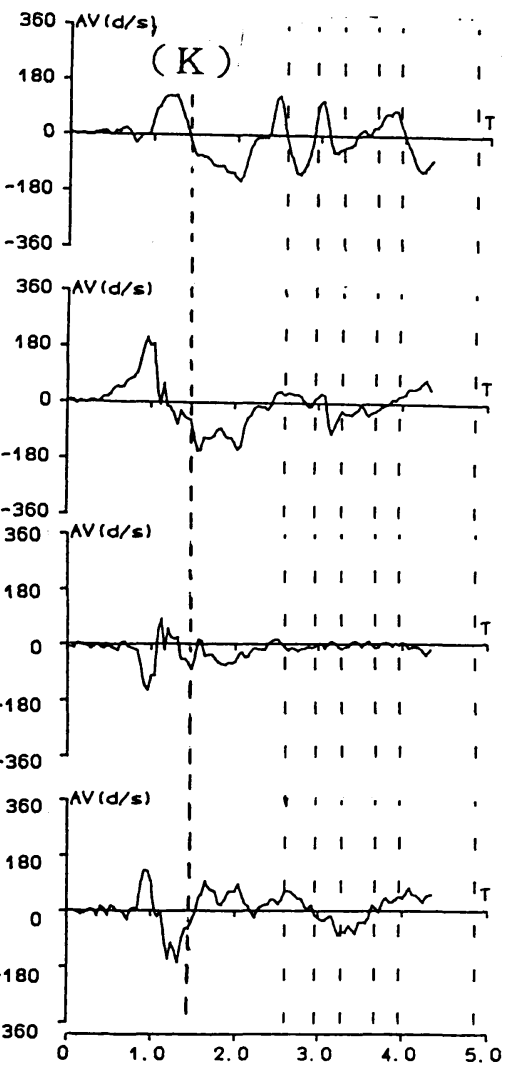

(b)

図 6 角速度 $\quad(\mathrm{K})$ : 膝関節届曲開始時点

(a)：椅子の高さは, $50 \mathrm{~cm}$. 足の位置は後方.（膝関節の伸展が先に生じる.)

(b)：椅子の高さは, $30 \mathrm{~cm}$. 足の位置は前方.（股関節，体幹の伸展が先に生じる.)

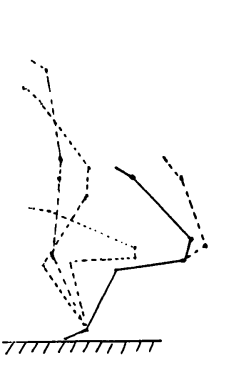

(a )

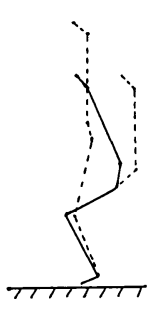

( b )

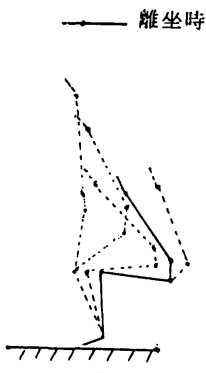

(c)

図 7 離坐時の重心と床反力作用点との位置的関係

(a)：足の位置は前方. 椅子の高さは $30 \mathrm{~cm}$.

(b)：椅子の高さは, $50 \mathrm{~cm}$. 足の位置は後方.

(c)：椅子の高さは, $30 \mathrm{~cm}$.下腿は垂直.

(a)(c)は, 前傾をより強く行うも, 重心と床反力作用点との前後距離が長い. 


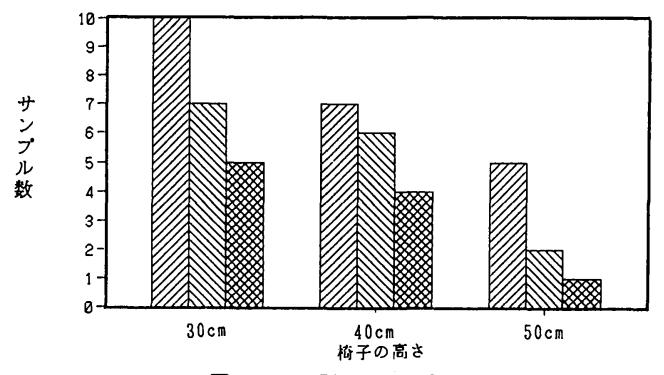

目足: 前方 $\mathbb{Q}$ 足:韭道足：後方

(a)

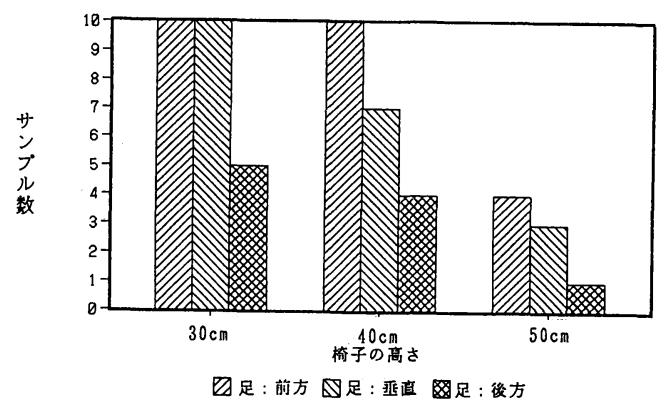

(b)

図 8 (a)：前方分力出現頻度 (b)：外側分力出現頻度 椅子の高さが低いほど，足の位置が前方である ほど, 出現頻度は高くなる。

\section{ま と め}

1. 椅子からの立ち上がり動作について, 椅子の高 さ, 足の位置との関連性の検討を行った。

2. 椅子が低いこと, 足の位置が前方であることは, 重心の移動が急激であることを要し, 自覚的困難性の 原因となる。

3. 困難性の指標として, 床反力の, 前方分力と外 側分力の出現があげられる.

4. 椅子は高さのみでなく, 足を後方に引くことの できる構造も重要である.

\section{文}

献

1）橋本幸生ほか：椅坐位から立ち上がり歩行開始動作 の分析. 中部整災誌，31：2127-2130，1989.

2）岩倉博光ほか：腰かけ動作としゃがみ動作. 姿勢研 究, $5(2): 69-77,1985$. 